\title{
"JAMAICAN SOUND KERONCONG": A COMMUNICATION STUDY ON THE SPREAD OF KERONCONG IN THE YOUNG GENERATION IN BANDUNG
}

\author{
Hery Supiarza $^{1}$; Cece Sobarna ${ }^{2}$ \\ ${ }^{1,2}$ Program Doktoral Kajian Budaya, Fakultas Ilmu Budaya, Universitas Padjadjaran \\ Jl. Raya Bandung Sumedang KM 21, Jatinangor 45363, Indonesia \\ 'herysupiarza@upi.edu; ${ }^{2}$ cecesobarna@yahoo.com
}

Received: $23^{\text {rd }}$ January 2019/ Revised: $04^{\text {th }}$ February 2019/ Accepted: $07^{\text {th }}$ February 2019

How to Cite: Supiarza, H., \& Sobarna, C. (2019). "Jamaican Sound Keroncong”: A communication study on the spread of keroncong in the young generation in Bandung. Humaniora, 10(1), 47-53.

https://doi.org/10.21512/humaniora.v10i1.5236

\begin{abstract}
This research discussed Jamaican Sound Keroncong (JSK) as a communication media in the global era. The problem of research was that keroncong music tended to be unknown by most young people in Bandung, and it was lost almost a century among them. This research aimed to examine the communication between the structure, agents (Sirlyai), and sub-agents (Crispy Crue/the fans), and the appreciation of the keroncong community in Bandung for their performances. Spredlay ethnographic methods were applied. Sirlyai was trusted informants and participatory observations, and in-depth interviews were carried out within one year. The research finds that; (1) Sirlyai creates a communication media product under the name of JSK as the binding structure between Sirlyai as the agent and CCI as the sub-agent; (2) the development of the internet creates dynamics and generates communication space; (3) communication of musical instruments is the basic idea of JSK product creation as communication media; and (4) there is a fundamental change of the old keroncong communication system to that of the youth keroncong in the global era. SirIyai is considered as the role model of the recent keroncong communication and becomes the parameter of creativity of musical mixture of global music era in Bandung.
\end{abstract}

Keywords: communication study, keroncong, young generation

\section{INTRODUCTION}

Bandung is one of the major cities in Indonesia after Jakarta and Surabaya. It is a city which is historically formed as a cosmopolitan population center. Therefore, it has a high tolerance for diversity values (Soeriaatmadja, 2017). The values are reflected by various musical communities throughout the city. The inter-communications among them cause various genres of music to flourish in Bandung. The smooth communication of the underground music communities is evident in Bandung's Ujung Berung area which has been acknowledged by international communities, such as Ujung Berung Rebels (Rostiyati \& Priyatna, 2017). The indie label music community and the majority of the musical communities are initiated by young adults. They move militantly, and this communal solidarity movement has an impact on the social life of the young adults in Bandung. It includes local Indonesian music; for example, keroncong music can have prospects and future (Supiarza et al., 2018).

Various musical performances are almost held every Saturday or Sunday. Such performances are not solely boring routine performances but rather professionally organized dynamic events by a large group of fans. Concerning young fans, it is stated that young people use music to express themselves to make claims about their identities One of the bands with its own community is Sirlyai, a group with thousands of teenage fans of junior and senior high schools who refer to their circle as Crispy Crue Indonesia (CCI). The community is closely connected to the cultural landscape as cultural work. The crucial factors in the community are the solidarity and the loyalty of its members, as well as financial support for the shows. Every community always has a leader who plays an important role in the community's life (Bathurst \& Ladkin, 2012). The leader has an important role in communication within the community, sub-communities, and external communities. The solidity and loyalty are determined by a leader who creates communication to unite the perceptions and togetherness. The leader determines how communication can create a strong network.

Keroncong is not a popular genre known by young adults in Bandung city. It is considered as foreign and old genre for almost all young adults in Bandung, besides the stigma of its being the music of the Javanese, especially the Central Java (Solo and Jogjakarta). In Bandung, keroncong position is still considered as traditional folk music; thus its development is not as dynamic as other musical genres 
(Supiarza et al., 2018). However, along with the technology development which is able to accommodate the creative and explorative nature of young adults, keroncong begins to ogle the young adults in Bandung gradually. They try to introduce keroncong in their own way, and it is able to be transformed into a relevant entity in the world of young adults in Bandung.

The movement to introduce keroncong music to young people in the city of Bandung in the global era has started since 2010, especially on campus (Supiarza et al., 2018). However, the communication concept of Sirlyai music group has the most significant impact, with the offer of a mixed music model called 'Jamaican Sound Keroncong' (JSK). It makes the popularity of keroncong music increased from 2011 to the present among young people in Bandung.

Keroncong has undergone a long metamorphosis process; therefore, it is called a hybrid cultural product (Ganap, 2011). It can adapt to any locality in which it is in. Keroncong in the 1920 s called 'Dixie' music which was a type of American music in the early 20th century and it was popular and trending in Indonesia (Suadi, 2017). Sirlyai's type of music has similarities to the keroncong type in the 20 s, especially in the use of wind instruments.

Based on the notes of several keroncong writers, one of its origins is influenced by Portuguese music (Ganap, 2011), and its distribution is based on the developed composition analysis. Budiman in (Supiarza et al., 2018) has divided keroncong based on three styles and rhythms, which are; (1) Jakarta style keroncong rhythm, (2) Surakarta style keroncong rhythm, and (3) Old style keroncong rhythm. These styles and rhythms refer to how it is played.

Meanwhile, Yampolsky (2010) has divided the style and rhythm (genre) of keroncong into four types, which are; (1) original keroncong, (2) Langgam, (3) Stambul, and (4) extra keroncong. For number 1, 2 and 3, each of them has benchmark, while for the extra keroncong, it is all types of music outside keroncong which is played in keroncong rhythm. As a category of popular music, the type of keroncong music makes it possible to have sub-genres such as Jamaican sound keroncong. Genre in the view of musicology according to Silver, Lee, and Childress (2016), "Music genre in this conception of human psychological categories is discerned by analyzing technical and psychological content and internal structures to musical works."

An interesting observation about SirIyai as the musical group is that their music genre is actually reggae, which is a kind of music that began to grow in the $1950 \mathrm{~s}$ from the lower society of Jamaica. Reggae comes from $\mathrm{R} \& \mathrm{~B}$, plus a variety of original musical elements from Africa as well as original music from Jamaica itself, which are Calypso and Mento (Johnson, 2015). Later, the majority of these genre musicians refer to this kind of music as 'Ska'. Meanwhile, Ska music was formed for political reasons in the 1960s when only a few American music recordings are able to enter Jamaica. Therefore, musicians and DJs tried to feature street musicians, and in the end, Ska music was able to enter the UK in the mid-60s (Johnson, 2015).

Musically, Reggae and Ska have the characteristics of various special continuously repetitive motifs (riff), and the most important thing is its lyric is the form of protest against white power over blacks. A bit of history about Reggae music above is not a stigma which then limits the idea of SirIyai to be silent and then obey the imported culture. Precisely, these young adults try to construct Reggae music by creating a new genre. In the author's interview with the frontman of this group (Personal Communication, January 25, 2018), a straightforward and innocent answer is given when they are asked, "What is your music genre?" They answer that their music is called 'Jamaican Sound Keroncong'. It is such an intriguing term in which 'Jamaican' is the name of a country in the Caribbean islands where 'Reggae' was born, 'Sound' means the sound of the entire ensemble music playing of keroncong.

From the explanation, it can be concluded that the meaning of this term is Jamaican music (Reggae, Ska, Rocksteady) mixed with keroncong which creates new collaborative sounds and becomes a subculture of the reggae and keroncong genres. This is an interesting problem in this research, where the activity of the Sirlyai music group raises a pro and contra attitude but instead makes a new discourse for the development of keroncong music among the younger generation of Bandung. This activity has provided positive energy for the development of keroncong music in the global era.

The research problem is that keroncong music is the type of music that tends to be unknown by most young people in Bandung. Almost a century of keroncong music is lost in the city of Bandung, and it is only played by parents as a medium of romanticism in the past.

The purpose of this research will comprehensively examine keroncong products with new forms in the global era called 'Jamaican Sound Keroncong' (JSK) as a communication medium, SirIyai as an agent and Crispy Crue Indonesia (CCI) as a sub-agent. This relationship creates reciprocal communication that is interesting to learn in reviving the spirit of keroncong development among young people in Bandung. It will prove that the Sirlyai group makes major changes through its communication model and Keroncong music has been favored by young people in the city of Bandung.

\section{METHODS}

There are two basic concepts for this ethnographic research method. First, Spradley has revealed the importance of discussing the concept of language, both in conducting the research process and writing the results in verbal form (Koeswinarno, 2015). In this case, the researcher explores the language of communication that occurs between Sirlyai and CCI as part of social interactions that are important for social phenomena. To study and review this language of communication, the researcher asks several ethnographic questions.

The main feature of postmodern ethnography is how Sirlyai and CCI use culture in their lives, and the center of research is also adapted to the minds of the people studied (emic). The second concept is informants as partners who collaborate with the researcher to produce cultural descriptions. Informants are sources of information; literally, they become teachers for ethnographers (Koeswinarno, 2015). Through this method, this research is expected to reveal more deeply and comprehensively about JSK as Sirlyai's communication media in relation to the CCI as appreciation and other supporting communities in conveying keroncong among the younger generation in Bandung.

The essence of Spradley's New Ethnography is an effort to pay attention to the meaning of actions from events that afflict people who want to understand through their culture (Koeswinarno, 2015). In this case, the researcher observes the actions around the agent in the music process, which affects them and who is influenced by them in 
strengthening the musical structure of Sirlyai and Crispy Crue as agents who interact.

In conducting fieldwork, researcher draws conclusions from the human culture from three sources; (1) from what people say, (2) from the way people act, and (3) from various artifacts used. This research is conducted using participant observation (Koeswinarno, 2015) in a relatively long time, namely the period 2017-2018 for almost one year with in-depth interviews that are conducted openly with Ade Dian (Iyai) and Muhammad Ershad (Midun). The two of them are used as trusted informants because Iyai is the leader of the music group Sirlyai, and Midun represents music group personnel as well as representations of Crispy Crue (fans).

In addition, to find out what responses from crispy crue as fans, the researcher conducts open interviews and the results of the researcher noted what they are as data from what people around them said. The researcher also takes part in the performance they do to see communication (JSK) running, observe the behavior of SirIyai and Crispy Crue and decode it. The researcher then collects various kinds of artifacts ranging from show photos, publication posters, t-shirt, hats, necklaces, and audio-video recordings, then used as supporting data.

\section{RESULTS AND DISCUSSIONS}

A mixture of two traditions (tradition and tradition) is a common thing in a mix of music to form a new genre or sub-genre. It has taken place for a long time, and it is a way for musicians to express their creative ideas. In addition, musicians are required to compete to create bombastic and spectacular issues so that the popularity and financial gains can be achieved. It relates to the theories of commodity fetishism and the cultural industry (Khadavi, 2014). Advanced technology and capitalism that dominates the world today encourage musicians as agents in the music industry structure to be competitive. In this case, pop music produced by the culture industry is dominated by two processes; standardization and pseudo-individualization (Khadavi, 2014). The competition to dominate and be legitimized by the industry creates new patterns in the music competition. Indie label movement shifted its paradigm in the 1970s.

Indie label is the idea that emerged from the concept of the English word, independent, which means free or boundless. This term is then standardized by indie musicians referring to a production system performed by a person or group of musicians rather than a recording industry owned by large investors (Sumrahardi, 2017). At present, they have to access media such as YouTube allowing music group to broadcast their music. In order to build a following, they are challenged to invite followers on their way to, dominance, and legitimacy, which is more likely to be achieved from the music industry structure. It is the aspiration sought by most music industry stakeholders such as Sirlyai. It occurs when the country is absent in providing regulations on the imperialism of musical culture.

Therefore, popular music in such country mostly follows the trend and gives little attention to mixing it with its local culture. A small part of it is the Sirlyai group. They have succeeded in creating the issue and entering the realm of industrial battle. When the government is busy with the jargon of 'preservation of art and culture', 'revitalization of traditional music', or 'local art of global taste' to name a few, the young generation of this nation has gone far beyond the ambiguities of such government jargon.

Sirlyai seems to be trying to rebuke and provide input on the thinking concept on the government's jargon of 'this is how to introduce keroncong to the young generation of the nation'. It is the term of how pop culture has become the ideological battle in order to achieve a hegemonic position in the emptiness of national power (Heryanto, 2018). In fact, the researcher finds that Sirlyai in its own way, success in introducing keroncong by mixing reggae and keroncong music and it should be admitted that there should be discussion and other writings on the 'mixing' in the context of music text.

In the global culture era, Sirlyai manages to give knowledge about keroncong to the young generation of Bandung by creating a new product or subculture called 'Jamaican Sound Keroncong'. Sirlyai-Crispy Crue Indonesia and JSK as products are the representation of the young generation's spirit in trying to appreciate keroncong so that it is sustainable in the new atmosphere. Dahl (2017) has referred it as music as a symbolic form of communication, which encourages the audience to respond accordingly with these interpretations. Moreover, such interpretations are integral to the knowledge of each listener.

The stage is the peak of communicant mass that showcases the expressions are conveyed in the composition of visualized the sounds, as the communication between the musician and the fans occur in the realm. Fans can be one of the change agents driven by the social criticism contained in the song lyrics (Sumrahardi, 2017). For Sirlyai fans, they are not only encouraged by the song lyrics, but also by the communication through mass media chats (Instagram, Facebook, Line, and YouTube), as well as small meetings routine that Sirlyai and the team initiate. Such meetings are informally conducted while consuming coffee; typical of interactions among the young generation of Bandung.

This communal communication aims to strengthen the relationship of the music group with their fans. In every performing events, Sirlyai's fan base named 'Crispy Club Indonesia (CCI)' that dominated by 14 to 17 years old enthusiasts (junior and high school students) come from various regions. They militantly come by bus, motorbike, and on foot wearing or bringing attributes agreed as their communal sign or 'vernacular texts' (Silver, Lee, \& Childress, 2016). They include flags, hats, t-shirts with 'CCI Jamaican Sound Keroncong' prints, and a picture of 'a skull donning a hat with crossing hammers' with the writing 'tradition $\mathrm{x}$ tradition $\mathrm{X}$ ' underneath (Figure 1). Sirlyai explains that the skull represents themselves, the hammer means the underclass workers, and the writing bonds are the mixture of Jamaican and local tradition (keroncong). The skull picture is an important symbol as it means of nonverbal communication depicting the group.

Figure 1 shows the agreed symbol as a symbol of the identity of SirIyai music group with CCI. Visible picture of skulls depicts the person/figure and behind the skull is hammer images which mean hard work. Then the writing of tradition $\mathrm{x}$ tradition is a narrative of the collaboration of keroncong music as a tradition of Indonesia and ska/reggae as Jamaican traditions which are incorporated into Jamaican Sound Keroncong (JSK). 'The boys and girls with a Crispy Power' text is a representation that fans are a force for SirIyai, and there are no levels in fans, all of them are equal. As Iyai has said (personal interview February 20, 2018), "In principle, it symbolizes my character, hard work, never giving up and always enjoying the process." 


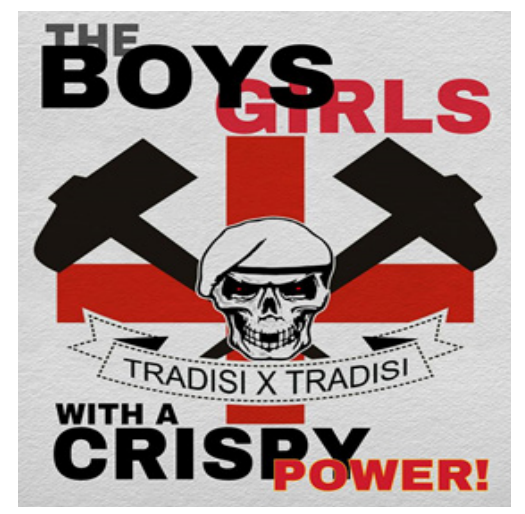

Figure 1 Sirlyai Logo

(Sirlyai Documentation)

In the interview with Iyai, the researcher has concluded that the music groups must have a brand that is able to differentiate from other groups. The brand must be a group character so that it can create a sense of belonging. Soeriaatmadja (2017) has said that "Individuals with such character also often look for objects and services that give a sense of belonging, so they tend to choose objects or brands that provide a similar appearance with other consumers of a particular brand or make them feel fit to the positive value from the community formed by the brand."

In the communication context by Soeriaatmadja (2017), it is applicable to CCI members that experience a sense of belonging. Gidden (Adiwijaya, 2011) has viewed that it is as a bond by interrelated and inseparable agents and structures with CCI as the agent and Sirlyai as the instigator of the interdependent structure. Attributes are a unifying symbol for agents both on and off the stage which solidifies the structure. Researcher finds that JSK is a communication media that unifies the language between the Agent and Sub-agent. Through JSK, SirIyai and CCI have a common taste. There are not many music groups that can create communication media in the form of other names outside the group. The interesting part is that Sirlyai can create a communication enhancement with another name outside of the core group, namely JSK.

Researcher finds that JSK has become a symbolic form that unites agents and sub-agents that makes the structure stronger. The power of JSK is clearly visible in the stage arena. The hypnotic symbols create a stage as the peak of communication between the agents and the sub-agents intertwined in a mixture of two traditions. Music is a rich and important site of symbolic consumption and could also be used in contexts other than music to describe symbolic consumption (Larsen, Lawson, \& Todd, 2010).

Processing of the communication, in this section, holds a crucial discussion on the main data sources which are of Sirlyai and Crispy Crue. The two names are identical with a two-sided coin, two elements in a binding structure like that of a mother and her child. The Sirlyai name is a combination of two words comprising of Sir (or 'master' in English) and Iyai which is the name of the founder, the leader and the vocalist of the group. Philosophically, it is a form of sarcasm to the surrounding social situation, where disappointment is directed to the policymakers and the social and the un-equality of the economic strata. It can be considered as irony, a subtle allusion with words contrasting their real meaning, like Femi Osofisan (Babafemi Adeyemi Osofisan), a Nigerian writer that is famous for his criticism of social problems. Through the drama, he uses music to mock his weaknesses, mistakes, and ignorance of character. Satirizes the political, the economic, and the religious life of Nigeria through the dramatic use of music is drawn on illustrations from his selected play (Adeleke, 2016).

Sirlyai comprises of 12 personnel who are either in high school or college. Iyai is a music alumnus from one of the universities in Bandung. Keroncong is the instrument composition that consists of the ukulele (cuk and cak); cello and contrabass that are played by high school students; while drums, flute, alto saxophone, trumpet, trombone, electric guitar and bass guitar that are played by college students. Keroncong instruments are played by tentative musicians. Sirlyai (personal communication, February 22, 2018), has stated, "... the nature of personnel remains, but there is always regeneration issues to anticipate absent members."

The results of this interview indicate that the personnel who play keroncong are teenagers who are still in high school, but their role is the most important in preserving keroncong. Technically, high school teenagers communicate keroncong by creating groups in their respective schools, and the results of these exercises are tested on every opportunity when Sirlyai performs. To test the versatility in playing keroncong, they are allotted with space in Coffee Industry the Cafe, located at Jl. Mentor no. 53 Bandung.

The cafe can be considered as the place where Sirlyai and Crispy Crue have verbal communication and a stage for the young generation of keroncong enthusiasts to perform and allow communication to occur filled with humor uniquely. The so-called art is a specific area of communication because what is communicated more dense and reflective (Smiers, 2009). It often occurs in a specific space, such as cafés in which there are screaming, laughing, commenting on keroncong, singing, and dancing. This is referred to as specific communication in music.

A publication poster for $\mathrm{CCI}$ in their regular meetings is made to strengthen brotherhood in the form of verbal communication. The image of young women tattooed with a relaxed appearance while drinking coffee is a symbol of today's young people who tend to be liberal and represent the CCI as a community of young people. In the poster picture, there is the text 'ngalageday' which is a verbal communication language of their creation as one of the symbolic texts of the adhesive relationship between agents and sub-agents. Iyai has said that (personal communication March 17, 2018), "ngalageday means too much to enjoy/ absorb something. This term just appears among CCI." It can be seen in Figure 2.

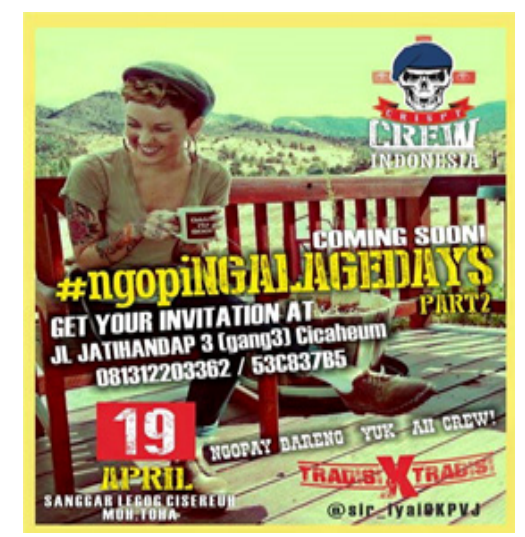

Figure 2 Example of Sirlyai and CCI Meeting Routine Publication

(Documentation: Sirlyai) 
Music has value for the listener. The communication that exists between the music played and the listener occurs because of mutual understanding of music knowledge (Dahl, 2017). The synergy between SirIyai and Crispy Crue is sustainably formed through regular communication to strengthen the structure and existence. Therefore, the space for the community in order to accommodate creativity makes keroncong in Bandung continues to grow until today. With the creation of communication media named JSK, researcher finds that it is the media to unite the same sense and avoid the level of class in the community. In addition, this research finds that communication patterns of the young generation in Bandung have reached their dynamic phase. Apart from, the context of Sirlyai and Crispy Crue with JSK, all types of youth community in Bandung are experiencing the same patterns of identity, equality, and family. However, the researcher also finds that the communication patterns established by Sirlyai-CCI and JSK in disseminating older or unpopular cultural types is considered as the most effective and successful. The researcher advocates that this communication pattern can be a role model for the development of obsolete music/art and its reconstruction in the global culture era.

Instruments communication creates (JSK) that does not occur only among the musicians (Sirlyai) but also the audience (CCI). There is another dimension that becomes an integral entity, which is how music communications progress (Corke, 2014). This research finds that a musical instrument is a communication media that unifies the perception of the music player, the perception that then produces sound as a representation of ideas.

In Srilyai's musical group, there is a collaboration between standard reggae musical instruments (bass, drums, guitar, keyboard, trumpet, trombone, and saxophone) with that of keroncong (cuk, cak, contrabass, cello, and acoustic guitars plus melodic instruments like flute or guitar). Collaboration between groups of musical instruments requires a special way of communication to not to stand alone or collide. In this research, the researcher finds the group's configuration of the instrument is deliberately arranged so that the communication can occur clearly in which the group of musical instruments reggae is positioned around the keroncong instruments. It can be seen in Figure 3.

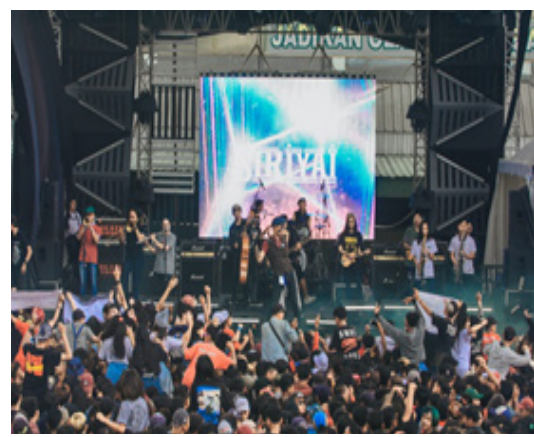

Figure 3 Instruments Placement Configuration (Sirlyai Documentation)

There is 12 personnel shown in Figure 3. There are five players in the inflatable equipment consisting of two saxophone players on the right and two brass players (trombone and trumpet) on the left plus one rather middle flute player. It is in the middle of three people with keroncong cello, cuk, cak, one bass, one guitar, and the back one is percussion/drum. While the vocalists are in the front position, they act as leaders and agents of communication with the audience. Regarding the configuration of this music player, Midun has explained that (Personal interview, September 10, 2018), "While the vocalists are in the front position, they act as leaders and agents of communication with the audience." Then regarding the configuration of music personnel, he has explained that, (Personal interview, September 10, 2018), "First is the position that is comfortable in communicating with fellow players, second is it looks good in the context of performances, keroncong personnel which plays (cuk, cak, and cello) who usually sit in a chair trying to stand." It must be known that this position in conventional keroncong music is something new.

The researcher concludes that two from the position of Sirlyai music personnel; first of all is intended to visually represent the combination of the two types of music, namely reggae and keroncong. Second is there is more intention to emphasize keroncong and its instrument group by positioning it in the middle of the stage. The audience can clearly distinguish the categories of the musical instrument groups. Then, in a musical composition, the researcher finds a maintained pattern of reggae (ska) and keroncong respectively while creating communication through the uniqueness of each genre.

In keroncong, there is a significant distinction of cuk and cak, the derivation of its historical name. The cello plays 'kendangan' or its percussive and communicative role which is crucial in keroncong. As an example of musical instrument communication in keroncong, the interaction of musical instruments and cak are shaped with the 'call and response' rhythmic pattern. The cello and the bass; communicate in resemblance of a kendang and a gong interaction in which at each cellos end is complemented by the bass. The banter musical instruments create a communication space that forms an integral sound called harmony, a unique sound of communication results called Jamaican Sound Keroncong.

Media to accommodate the idea exchange, the advancement of communication technology, called the internet, allow global connection for its citizens. Sullins (2017) has stated that "We live in the first era throughout human history when everyone can communicate with anyone." Technology has an important role in community communication activities that are able to increase the quality of life, including in social, politics, education, and culture aspects (Omar, Rahim, \& Othman, 2017). The revolution combination of Internet-computer creates a new generation which is more dazzling than the revolution created by the findings of printing, radio, automobile, and television (Valkenburg, Patti, \& Piotrowski, 2017). Similarly, in the world of music, people can easily access everything they want to know about the development and trends of music and anything available on the internet (Lennon, 2016). The use of communication technology requires three dimensions, namely access, skill, and motivation (Omar, Rahim, \& Othman, 2017).

This research has found that the Internet is a very important media of communication for the exchange of ideas between SirIyai and CCI. Through Instagram, Facebook, and YouTube, the communication of ideas is intertwined. The researcher has found an exchange of ideas in this realm, in addition to the video of Sirlyai show as well as many CCI videos uploaded with the purpose of showcasing their ideas on musical performances or arrangements they proposed or wanted. Sirlyai and CCI's proficiency in managing the internet media provide more frequent communication 
activity, so that the information is relevant and it makes the relationship between SirIyai and CCI closer.

The interaction between the composer and the listener takes place where SirIyai as the composer has conveyed his intention, and the listener or CCI has understood and experienced the experience created by Sirlyai (Corke, 2014). It extends to other people or communities outside the immediate circle. The influence is formed because the internet media is accessed by the world community, so the internet also contributes greatly to touted growing SirIyai fandom. From Sirlyai (Personal Communication, March $9,2017)$ has stated that "... if almost every region in West Java has a base, 10 thousand people and approximately 100 regional coordinators will have access to the record. A network outside West Java also exists, but the detailed record has yet to be made. Hopefully, after the completion of the second album, it will be re-recorded." By tacitly applying what Corke (2014) has said about communication media, SirIyai has caused effects for CCI in receiving music through JSK.

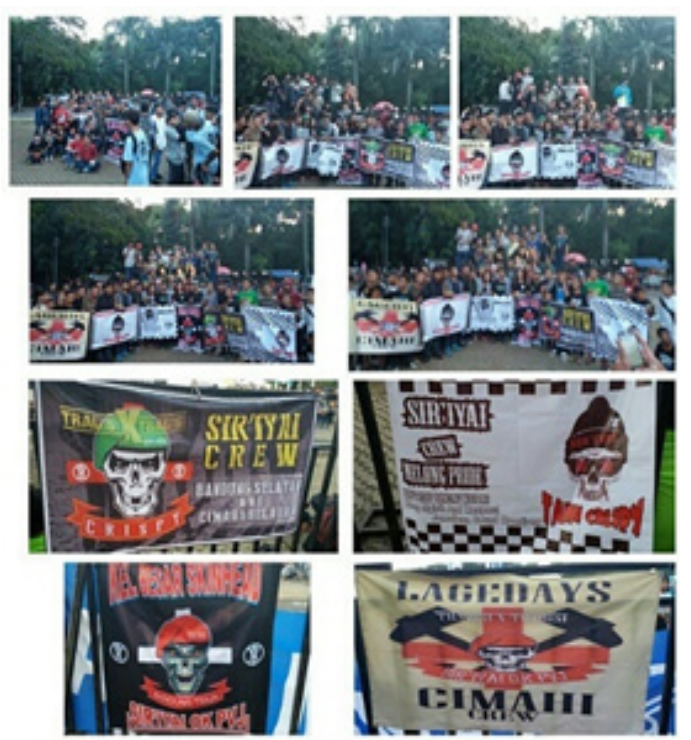

Figure 4 CCI Logo Examples from Each Region (Sirlyai Documentation)

Figure 4 shows some CCI communities communicate directly with community flags that describe the origin of their area. This proves how the effect of communication through social media can effectively strengthen a music community between musicians and fans. Sirlyai proves through the communication media JSK that the communication relationship between SirIyai as a communicant could popularize keroncong music with many fans in young people in Bandung.

The results of the research have found that the development of communication media in the era of global culture has contributed significantly to SirIyai's musical ideas in creating forms of keroncong music communication and it is superior in communicating keroncong music to young people in the city of Bandung. Sirlyai is considered a performance model of contemporary keroncong music and has become a creative parameter mixing music culture in indie label music in Bandung, even in other cities in Indonesia. Since 2010 until now, keroncong music in the city of Bandung has grown significantly compared to the previous period and has been converted into Keroncong
Sound Jamaica.

Communication relationship through the internet creates a more open communication system of ideas and criticisms. Ideas often yield shows and even song creation. They do not only appear as new music composition for Sirlyai as the communicator but also provides many creative things for CCI playing a communicant role. Sullins (2017) has stated that the media construct the formation of the reality of daily life. In the context of this research and as mentioned explicitly at the end of the article, the researcher has found the communication synergy of Sirlyai and CCI creates the role model for the preservation of keroncong in the global era by offering its communications named Jamaican Sound Keroncong.

\section{CONCLUSIONS}

SirIyai and CCI project themselves is a role model for the community and policymakers on cultural preservation. Through JSK as a communication media of keroncong, Sirlyai and CCI have succeeded in preserving it with a communication model based on technological progress which is the internet. Keroncong as a part of the Indonesian culture, therefore, can be recognized and appreciated well by the young generation of Bandung and other parts of Indonesia. The young generation is a change agent that able to revive the genre while retaining the original value in its new form. The novelty for the young generation lies in the condition under which change in all fields is a necessity, and as predecessors, they should be given the creative space by the policymaker, in this case, is the government.

Jamaican Sound Keroncong (JSK) is a product of an idea from Bandung's young generation that provides fresh air for the revival of keroncong in Indonesia. Through social media such as Instagram, Facebook, and YouTube, the young generation can use them to make significant interaction, which then affects the preservation of keroncong among the young generation in Bandung.

This research has found that the communication of keroncong among the young generation in Bandung has experienced a period of significant progress in the era of global culture. The communication through the world of technology, community, and musicality has given it a new issue for its development among them. It can be said that the present era is its development keroncong in the modern era, a new period from the previous period. It is also proven that its communication system keroncong older generation has metamorphosed into that of the modern era. The discovery of the Internet has made the communication system more dynamic at present to provide opportunities for such systems to be more developed.

Meanwhile, in the elderly, its conventional communication system underdeveloped the distribution of keroncong. Parents hide behind the grip (keroncong rule) because of the inability to adapt to the development of communication technology, especially the internet. This research has contributed in the academic world by exposing the way the young generation preserves keroncong through JSK as a communication media keroncong in the global era and a real impact on the spread and the growth of keroncong among them today.

An implication of this research is the need for the attention of the Indonesian government in making a cultural policy regarding the preservation of the arts by involving the young generation who have succeeded in creating 
and applying their ideas. Such policy should be based on empirical studies to ensure its real and relevant capability in encouraging the emerges of the products. While the limitations of this research are that in-depth music analysis is not well revealed due to the limited time of the research. With music analysis, research can reveal personal messages, social conditions, and various things expressed through the music itself.

As for future recommendations, the researchers can ignite other discussions and actions on this issue of the preservation of original Indonesian music among millennials where technology can easily become a media for notifying the wealth of Indonesian music. Social media is an important part of the life of modern youth and can be used to communicate with young people in other hemispheres. This rapid interaction between parts of the world is a reality that must be seen wisely in the context of promoting genuine Indonesian music.

\section{ACKNOWLEDGEMENTS}

I wish to extend my heartfelt gratitude for the extraordinary support for my research from Prof. Cece sobarna as the chairman of the promotors, Dr. Phil. Sukmayadi and Dr. R.M. Mulyadi as co-promoters. My sinceresr appreciation is for Dr. Aquarini Priatna who is a reviewer of this research as well as a lecturer in international journals writing course that has provided many notes for writing materials. I am indebted to Sir Iyai as a resource person interviewed in giving so much data about the keroncong - orchestra. LPDP Budi-DN for awarding the financial support for completing this research and the 3- year study in Cultural Studies at the Faculty of Cultural Sciences, Universitas Padjadjaran, Bandung.

\section{REFERENCES}

Adeleke, E. B. (2016). Music as an agent of satire in selected plays of Femi Osofisan. Africology: The Journal of Pan African Studies, 9(2), 28-41.

Adiwijaya, D. R. (2011). Semiologi, strukturalisme, poststrukturalisme, dan kajian desain komunikasi visual? Humaniora, 2(1), 803-813.

Bathurst, R., \& Ladkin, D. (2012). Performing leadership: Observations from the world of music. Administrative Sciences, 2(4), 99-119. https://doi.org/10.3390/ admsci2010099.

Corke, M. (2014). Approaches to communication through music. London and New York: Routledge, Taylor\& francis Group.

Dahl, P. (2017). Music and knowledge: A performer's perspective. Rotterdam: Sense Publishers.

Ganap, V. (2011). Keroncong toegoe. Yogyakarta: BP ISI.

Heryanto, A. (2018). Identitas dan kenikmatan. Jakarta: PT Gramedia.

Johnson, B. (2015). Jamaican popular music: From Mento to Dancehall reggae. Latin American Music Review, 36(2), 283-285.

Khadavi, J. M. (2014). The deconstruction Indonesia music pop in perspective industry culture. Jurnal Humanity, 9(2), 47-56.

Koeswinarno. (2015). Memahami etnografi ala Spradley. Jurnal SMaRT, 1(2), 257-265. Retrieved from http:// blasemarang.kemenag.go.id/journal/index.php/ smart/article/download/256/176.

Larsen, G., Lawson, R., \& Todd, S. (2010). The symbolic consumption of music. Journal of Marketing Management, 26(7-8), 671-685. https://doi.org/10. 1080/0267257X.2010.481865.

Lennon, J. (2016). Music in the digital age: Musicians and fans around the world come together on the net. Global Media Journal, 9(1), 1-25.

Omar, F. I., Rahim, A. S., \& Othman, A. N. (2017). Penggunaan internet dalam kalangan usahawan wanita: Akses, kemahiran dan motivasi. Malaysian Journal of Communication, 33(3), 21-36.

Rostiyati, A., \& Priyatna, A. (2017). Punk women: Counter culture against normative gender (A study case in Cijambe village Ujung Berung). Patanjala, 9(2), 261-276.

Silver, D., Lee, M., \& Childress, C. C. (2016). Genre complexes in popular music. PLoS ONE, 11(5), 1-23. https://doi.org/10.1371/journal.pone.0155471.

Smiers, J. (2009). Art under pressure. Yogyakarta: Insistpress.

Soeriaatmadja, K. (2017). Consumer tribe dan industri gaya hidup di Bandung, Indonesia. Jurnal Keamanan Nasional, 3(1), 150-169.

Suadi, H. (2017). Djiwa manis indoeng disajang, musik dan dunia hiburan tempo dulu. Bandung: PT. Kiblat Buku Utama.

Sullins, J. (2017). Information technology and moral values. Standford: Metaphysics Research Lab, Stanford University.

Sumrahardi, A. (2017). Ekonomi politik musik rock. Jakarta: LP3S.

Supiarza, H., Sobarna, C., Sukmayadi, Y., \& Mulyadi, R. M. (2018). The prospect and future of youth kroncong group at Universitas Pendidikan Indonesia in Bandung. Harmonia: Journal of Arts Research and Education 18(1), 52-61. https://doi.org/10.15294/ harmonia.v18i1.15524.

Valkenburg, M., Patti, Piotrowski, T. J. (2017). Plugged in: How media attrack and affect youth. Connecticut: Yale University Press. https://doi.org/10.1360/zd2013-43-6-1064

Yampolsky, P. B. (2010). Kroncong revisited: New evidence from old sources. Archipel, 79(1), 7-56. https://doi. org/10.3406/arch.2010.4159. 